\title{
Anthós
}

Volume 10 | Issue 1

Article 4

$6-21-2021$

\section{Globalizing Noncitizen Detention}

Jaye Balentine

Portland State University

Follow this and additional works at: https://pdxscholar.library.pdx.edu/anthos

Part of the International Relations Commons, and the Political Economy Commons

Let us know how access to this document benefits you.

\section{Recommended Citation}

Balentine, Jaye (2021) "Globalizing Noncitizen Detention," Anthós: Vol. 10: Iss. 1, Article 4.

https://doi.org/10.15760/anthos.2021.10.1.4

This open access Article is distributed under the terms of the Creative Commons Attribution-NonCommercialShareAlike 4.0 International License (CC BY-NC-SA 4.0). All documents in PDXScholar should meet accessibility standards. If we can make this document more accessible to you, contact our team. 


\section{Anthós}

Volume 10 | Issue 1

Article 4

$6-21-2021$

\section{Globalizing Noncitizen Detention}

Jarod Balentine

Portland State University

Follow this and additional works at: https://pdxscholar.library.pdx.edu/anthos

Part of the International Relations Commons, and the Political Economy Commons

Let us know how access to this document benefits you.

Recommended Citation

Balentine, Jarod (2021) "Globalizing Noncitizen Detention," Anthós: Vol. 10: Iss. 1, Article 4.

https://doi.org/10.15760/anthos.2021.10.1.4

This open access Article is distributed under the terms of the Creative Commons Attribution-NonCommercialShareAlike 4.0 International License (CC BY-NC-SA 4.0). All documents in PDXScholar should meet accessibility standards. If we can make this document more accessible to you, contact our team. 


\section{Globalizing Noncitizen Detention}

Jaye Balentine

\section{Introduction}

This inquiry seeks to establish that the global expansion in regimes of noncitizen detention represents a contemporary expression of imperial subjectification under Western liberalism and that such regimes serve a key role in maintaining the capitalist social order. Beginning with a discussion of the nature of noncitizen detention and its consequences, this effort will then argue that an effective analysis of this topic requires an acknowledgement of the liberal political ideology which shapes regimes of noncitizen detention and the process of imperial subjectification characteristic of the capitalist social order. Using theoretical frameworks concerning liberalism and the capitalist social order, this inquiry will explore the existing efforts of theorists to explain the innovation of detention practices in the United States and the diffusion of these systems to other nations. Two approaches have been offered by the existing literature: the first is the concept of "policy diffusion" (Flynn, 2014) which argues for a systematized analysis of policy innovations drawing on international relations scholarship while the second is an analysis of noncitizen detention as an aspect of global capital flows and the commodification of immigration (Bales \& Mayblin, 2018; Morris, 2019). While each of the existing approaches have strengths and weaknesses, each could be improved by more substantial acknowledgements of liberalism and the functionality of the capitalist social order, particularly the presence and role of racialization. In a world of increasing migration driven by climate breakdown and worker precarity under late-stage capitalism, understanding the systems of migrant control practiced by core countries is of crucial importance to scholars, policy makers, and anyone concerned about the human costs of such practices.

\section{Background}

\section{Understanding Noncitizen Detention}

Before exploring the policies and practices that constitute contemporary regimes of noncitizen detention, it is necessary to understand how this form of imprisonment functions and why states choose to employ it. Lauren Martin (2015, p. 234) considers such questions, explaining that detention represents "a 
particularly spatial practice that bounds space in order to prevent bodily mobility." This control over migrant bodies serves several functions. Martin (2015, p. 234) notes that processes traditionally limited to border areas (identification, inspection, etc.) are "reterritorialized," expanding regimes of border control both internally and externally_as detention centers can be constructed throughout a state's interior as well as in peripheral countries. Such centers are often located remotely, Martin (2015, pp. 234-235) continues, isolating migrants from existing social networks and communities. Similarly, administrators use transfers between facilities as a form of discipline, further isolating individuals and preventing organized dissent.

These practices reinforce the authority of the immigration officials and serve as an important site of 'subjectification': the relegation of an individual to a particular role or definition by an authority. As noted by Martin (2015, p. 235), this subjectification functions by both reaffirming the 'otherness' and the 'criminality' of migrants, accomplishing the former with the centering of nationality via the process of deportation and repatriation, and the latter through imprisonment and forced mobility. This subjectification, built around the citizen/noncitizen dichotomy, is central to understanding the process of migrant detention. It represents the boundary drawn between those to whom liberal democracies extend individual rights - to due process, bodily autonomy, access to labor markets, etc. - and those denied such rights.

\section{The U.S. Model of Noncitizen Detention}

An effective analysis of noncitizen detention requires the U.S. as a starting point due to its role as the innovator of such systems, a fact noted by numerous scholars (Bales \& Mayblin, 2018; Flynn, 2014; Gottschalk, 2014; Martin, 2015). Marie Gottschalk constructed a comprehensive history of the U.S. carceral state in her monograph Caught: The Prison State and the Lockdown of American Politics (2014). Dedicating a lengthy section to the history of the U.S. immigration system, Gottschalk (2014, pp. 215-240) emphasizes that what led to such a punitive and carceral character was the convergence of the immigration and criminal justice systems. Gottschalk (2014, p. 234) points to a series of policies, beginning in the 1990's, which began to more closely integrate Immigration and Naturalization Services (INS) and law enforcement. Of note are the Antiterrorism and Effective Death Penalty Act (AEDPA) and the Illegal Immigration Reform and Immigrant Responsibility Act (IIRIRA), both of which "provided the legal 
means to expand the use of mandatory detention of noncitizens without bond" (Gottschalk, 2015, p. 221). Similarly, they "curtailed judicial review and due process in immigration cases," transitioning authority away from the judiciary and into the hands of administrators in the INS. The limiting of due process for migrants represents a denial of rights purported to be universal by liberal political ideologies.

Following the 2003 creation of the Department of Homeland Security, various segments of the immigration enforcement system underwent a reorganization and found themselves flagged for a dramatic increase in funding (Martin, 2015, p. 238). It was during this transition that the U.S. government restructured the INS, creating Immigration and Customs Enforcement (ICE). Gottschalk (2014, pp. 221-222) describes how under ICE, the resources dedicated to the active pursuit of undocumented migrants - as opposed to identification and detention at border facilities - expanded greatly. ICE adopted police tactics such as home raids, described as when "“armed [ICE] agents arrive at the homes in the early morning hours, bang hard on the doors and windows, and falsely identify themselves as the 'police,' whereupon they force the door open to enter the homes with guns drawn"' (Gottschalk, 2014, p. 221). Not only serving as an instructive example of the blurring of lines between immigration enforcement and policing, such activities expanded the immigrant detainee population to record numbers. Though the required average daily number of detainees is 34,000 - the very existence of such a mandate is notable - over 400,000 individuals passed through ICE detention facilities in 2010, having doubled since 2002 (Gottschalk, 2014, 219). This begs the question: how did ICE go about constructing and supplying such a large scale carceral institution?

The answer is that an industry specializing in the business of imprisonment had already developed. As Gottschalk (2014, p. 233) explains, the private firms which had developed around the prison expansion in the U.S. starting in the 1970's and 1980's had, in fact, been an influential interest group in passing immigrant detention legislation. Spending large amounts of money on lobbying efforts, these industries exploited both lucrative federal contracts as well as state and local contracts - often selling detention centers as an economic boon to struggling areas, whose financial burdens were exacerbated by the 2008 recession. The development of the noncitizen detention complex in the U.S. has been consistently conducted via such private-public partnerships. It is 
unsurprising, then, that in the era of globalizing capitalism, this industry would find its way abroad.

\section{Globalized Detention}

There exists a lack of comprehensive research on the spread of noncitizen detention programs. What work does exist finds itself limited due to a lack of acknowledgment of the role of liberal political philosophy and the racialized capitalist social order in shaping and legitimizing such regimes of detention. It is only through incorporating theoretical lenses concerning these two phenomena that a more penetrating and salient analysis of the spread of noncitizen detention may be developed. The following sections will introduce two theoretical frameworks which serve this purpose, before employing these frameworks to critique and improve upon the extant literature on the spread of regimes of noncitizen detention.

\section{Liberalism and the Racialized Capitalist Social Order}

The first framework concerns the nature of liberal political philosophy, and its role in shaping these systems of detention. Lisa Lowe (2015, p. 39), illustrates how liberal ideologies of universal, individual freedoms emerged in the context of empire, explaining that "colonized peoples created the conditions for liberal humanism, despite the disavowal of these conditions in the European political philosophy on which it is based." Thus, rather than challenging the violent oppression of those living under European domination, liberalism in fact facilitated such processes. Lowe (2015, p. 39) continues, noting that "“freedom' was constituted through a narrative dialectic that rested... on a spatialization of the 'unfree' as exteriority." This free/unfree dichotomy remains central to Lowe's analysis of liberalism, given that rather than liberating the "unfree," those societies which embraced liberal ideologies owe their ongoing existence to that very unfreedom. Lowe substantiates this claim by pointing to the colonial conditionality of liberal nations and their economies. This dichotomy serves as an illustrative context in which to situate our discussion of noncitizen detention.

In the inquiry at hand, one simply substitutes free/unfree with citizen/noncitizen. In this context, the rights enjoyed by the free-access to wealthy labor markets, the right to due process, protection from arbitrary detention and forced mobility, etc.- - exist not as universals, but as deeply conditional. These rights only hold meaning in the presence of those denied such 
rights. Similarly, the relative wealth of the Global North only exists because of the cheap labor and unregulated extraction carried out in the Global South. Wealthy liberal democracies must violate their own ideological tenets to produce the so-called "human rights" afforded to their citizens. As such nations continue to engage in the arbitrary detention of noncitizens, the citizens themselves should note the fragility of their own claims to these supposed "rights," and be wary that their governments demonstrate such a willingness to violate them.

The second conceptual framework relies on a similar dichotomy, that of exploitable/expropriable. Developed by Nancy Fraser $(2014 ; 2016)$ and Michael Dawson (2016), this dichotomy is grounded in what Fraser (2014, p. 60) identifies as "expropriation." Fraser builds upon Marx's critique of capitalism, which identifies the so-called "front-story" of capitalism — exchange - as a façade, obscuring the "back-story"-exploitation. Fraser expands this conception, however, to uncover a third realm: that of expropriation. Characterized by Marx (1867/2011, p. 784) as "primitive accumulation," his mistake was restricting this process to the origins of capitalism. Rather, as Fraser $(2014$, p. 86) illustrates, the process of expropriation — outright theft, as opposed to contracted, though exploitative, labor - is an ongoing feature of the capitalist social order. Dawson (2016) expands on Fraser's work to note that racialization serves as a crucial factor in determining who under capitalism suffers exploitation and who suffers expropriation. Dawson (2016, pp. 147-149) offers the "ontological distinction[s]" of "inferior/superior," "human/subhuman," "full citizens/second-class citizens," and "civilized/uncivilized." What these distinctions represent, in Fraser's (2016, p.169) language, are the distinctions between the "free exploitable citizen worker" and the "dependent expropriable subject." This division, and the theoretical construction which underlies it, applies directly to the detention of noncitizens.

As discussed previously, a key feature of detention is the subjectification of immigrants as "others" and "criminal." Here I argue that this contributes to the broader subjectification of noncitizens as racialized, expropriable subjects. This subjectification plays the crucial role of differentiating distinct populations under the capitalist social order. The institution of capitalism needs to deny these migrants rights, needs to deny them access to labor markets and due process, because otherwise the very foundations of both exploitation and expropriation become threatened. The fact that the territorial boundaries along which these divisions exist form the frontiers of the Global North - those states controlled by either indigenous Europeans or the descendants of European settlers - constructs 
what Fraser $(2016,171)$ terms an "imperialist geography." Such a geography, partitioning the world into exploitable imperial citizens and expropriable - and racialized - subjects requires enforcement and maintenance. This is the role of today's regimes of noncitizen detention.

\section{Policy Diffusion}

Michael Flynn, in his article "There and Back Again: On the Diffusion of Immigrant Detention" (2014), offers an analysis based on "diffusion theory." This theory, developed in international studies, offers a framework for the spread of policies between different states. Flynn (2014, pp. 169-170) draws on the work of Sandra Lavenex and Emek Uçarer (2004) to offer a four-part "policy transfer framework." The four dynamics identified are: 1) unilateral emulation; 2) adaptation through externality; 3) opportune conditionality; 4) inopportune conditionality. Flynn (2014, p. 169) describes unilateral emulation as instances in which a state opts to adopt the policy of another on its own initiative. Adaptation through externality concerns instances involving "a mix of voluntary and involuntary adaptation that occurs when a state elects to adopt a specific policy in response to the impact of policies adopted by a neighboring country." Opportune conditionality refers to when a state has policies imposed on it by another, but the change is welcome by the adopting state. Inopportune conditionality refers to the opposite, in which an unwelcome imposition occurs. This framework offers some interesting insights on the topic at hand.

Australian policy adoptions represent an instance of unilateral emulation. Flynn (2014, pp. 180-184) notes that Australian officials looked to the example of U.S. detention practices in developing their "Pacific Solution." Introduced in 2001, the program entailed the detention of migrants apprehended by Australian authorities on the surrounding island nations of Papua New Guinea and Nauru. Officials modeled the program specifically after U.S. foreign detention practices at Guantánamo and other offshore facilities, with a section of the parliamentary notes titled "The United States Analogy" (Flynn, 2014, p. 180, 182). Flynn, with coauthor Cecilia Cannon (2009, pp. 4-5), notes that the reliance on private contracts represents an additional important parallel to U.S. practices. The Australian government turned to Australasian Correctional Services (ACS), a company servicing prisons and detention facilities. Once again, the industry which developed around the privatization of prisons stepped readily into a new role as detainers of noncitizens. Continuing the chain of diffusion, Flynn (2014, p. 
185) points out that both Canada and New Zealand looked to Australia as an example for developing their own immigrant detention regimes, noting Canadian officials touring Australian detention centers and New Zealand adopting legislation which allows for the sharing of facilities with the Australian government.

In the European context, states have emulated both the Australian and U.S. examples, though with important regional specifics. Though certain states, such as the U.K., have readily pursued expanded detention programs, "periphery EU states" tend to bear most of the burden (Flynn, 2014, p. 186). Greece has been singled out as ideally located for migrant detention, the efforts for which were funded by the EU. This example mirrors the U.S. policy in Central America and the Caribbean, where the U.S. transfers noncitizens to third-party states such as Guatemala. The third-party typically lacks facilities and resources to house the detainees, and must apply for funding from the U.S., often taking the form of private contracts - to clarify, the result are contracts between the third-party state and private detention firms funded by the U.S. (Flynn, 2014, p. 178). Such examples serve as instances of either adaptation through externality, or-perhaps more aptly_inopportune conditionality, as the third-party states often enter into the process at a severe power imbalance.

Flynn's work highlights a two-part trend. First, is the consensual adoption of noncitizen detention policies by other wealthy receiving countries. The U.S. remains centered as the pioneer of the strategies involved, with other receiving countries observing and consulting with the U.S. to develop their own. The second aspect is the more coercive spread of detention systems to countries peripheral to these receiving states. From Guatemala to Nauru, these states stand on unequal footing in the international arena and find regimes of detention imposed on them by more powerful nations. Throughout both processes is the ubiquitous presence of private firms - typically based in the prison industrybuilding, maintaining, and supplying detention centers. Though this analysis provides a compelling framework, the systemization of the process may in fact obscure certain factors. Missing is any substantial acknowledgement of the history of European imperialism, while the paper focuses almost entirely on either European or Euro-settler states. The "power imbalances" noted in the paper seem to exist in a vacuum, rather than situated in a history of violent colonialism and oppression perpetrated by the very states which now detain impoverished migrants without due process and with considerable human rights abuses. While 
these omissions may simply be symptomatic of the aim of the paper-to contribute to and build off policy diffusion scholarship - they limit the analytic depth of the effort.

\section{Global Capital}

A centering of global capital serves as another lens through which to analyze the globalization of regimes of detention. The ever-present private firms and their accompanying profit motives are a key feature of noncitizen detention programs. Comprehensive studies into this topic are lacking, though several existing scholarly efforts provide some starting points.

Katie Bales and Lucy Mayblin (2018) explore the role of labor in noncitizen detention centers in the U.K., concluding that such practices are fundamentally exploitative and coercive. Bales and Mayblin (2018, p. 197) describe how in 2006 the government introduced "paid activities" to the U.K. immigrant detention system. The practice was, in keeping with the present analysis, pioneered in the U.S. to lower the costs of running detention centers (Bales \& Mayblin, 2018, p. 192). Not categorized as employment, such activities are not subject to any minimum wage laws nor worker protections, supposedly existing to alleviate boredom among detainees. Yet most activities pertain directly to the upkeep of the facilities, with the authors noting that 'detainees' work is integral to the running of the detention centers, reducing the need for paid staff who would otherwise fill these positions" (Bales \& Mayblin, 2018, p. 197).

In a government run facility, such practices would work to reduce the public burden of financing the center, albeit with serious ethical concerns about the ability of detainees to truly consent to such activities. However, private firms run most of these facilities, changing the dynamic into one in which cutting costs allows for a greater extraction of value. Bales and Mayblin (2018, p. 196) explain that "the corporations currently running the removal centers are G4S, Mitie, GEO and Serco, while a small number of centers remain under the management of HMPS." The corporation G4S is of note, given that in 2002 it purchased the parent company of (the aforementioned) Australasian Correction Services and now runs detention centers throughout both Europe and Australia (Flynn \& Cannon, 2008, p. 5). One cannot help but note the contradiction between the violently limited mobility of migrants (by states and their affiliated corporations) and the lack of constraints on the global movement of capital. 
Julia Morris (2019) further emphasizes the political economic nature of globalizing detention regimes. Exploring Australian detention facilities in Nauru, Morris (2019, pp. 1123-1124) conceptualizes of detained migrants as commodities, following the Marxian understanding of the term. Morris's analysis emphasizes two key points. First is that migrants themselves have become commodified, in that their relocation to detention centers is the precise source of extracted value for private firms (Morris, 2018, p. 1124). Second is that the political economy of detention centers mirrors David Harvey's (2006) work on dependency theory. Harvey (2006) emphasizes that "uneven development" results in perpetually underdeveloped regions, typically in the Global South, which exist in a constant state of dependency on the core nations of the Global North. Central to such an analysis is that this underdevelopment is not incidental, but characteristic (and arguably fundamental) to the global capitalist economy. Morris (2019, p. 1125) notes that throughout the twentieth century Nauru existed essentially as a company town, dependent entirely on phosphate extraction (run by foreign administrators and corporations). Beginning in the early 2000's, however, Nauru transitioned to a new industry: detaining refugees and other undocumented migrants apprehended by Australian authorities (Morris, 2019, p. 1126). This process - using the detention industry as a short term and fundamentally extractive economic boon for a local community-mirrors the activities of detention firms in the U.S. described above by Gottschalk (2014, p. 233). This tactic was in fact developed even earlier, by the U.S. prison industry. Theorist of racial capitalism Ruth Wilson Gilmore $(2007,87)$ termed this tactic the "prison fix," where prison corporations would leverage the poverty of economically depressed rural areas to build incarceration facilities offering employment opportunities for residents. However, as with Nauru, these dynamics serve the profit motives of the corporation and leave the community in a state of dependency on the "foreign" investor.

By viewing the global spread of regimes of noncitizen detention through the lens of global capital, we can develop a clearer view of the political economic structures influencing this expansion. The mobility of capital across borders - in contrast to the immobility of migrants and refugees caught up in the noncitizen detention industry-highlights that these vested interests possess both the means and the motives to encourage expansions in detention globally. However, this analysis still lacks any substantial acknowledgement of how subjectification processes - particularly racialization — serve to legitimize such practices. The 
political economic analysis offered here provides a thorough analysis of the structural machinations of regimes of non-citizen detention yet could be improved by a recognition of the superstructural aspects which facilitate the process. Notably, this would include the ideological productions offered by the liberal political philosophy in categorizing those experiencing detention as the unfree, racialized populations often treated as disposable by liberal democracies. By including both the structural and ideological aspects of these regimes, a clearer picture of the purpose and function of noncitizen detention forms: where the functional side is characterized by a defense of an imperial geography and value extraction from expropriable populations, while the ideological side serves to legitimize and 'justify' such processes through racialization.

\section{Conclusion}

This inquiry has sought to establish that the global spread of regimes of noncitizen detention warrants analysis due to both the human costs of such systems, as well as their increasing significance in an era of climate breakdown and precarious late-stage capitalism. After establishing the background of such regimes - rooted in U.S. carceral practices - this effort sought to explain that an effective analysis of the spread of these regimes requires the acknowledgement of liberal political philosophy and the racialized capitalist social order. These are the phenomena which are responsible for bringing such regimes into existence, given that the stability of this social order requires securitized defense - in this case, the securitized defense of its imperialist geography. Such a system of defense is legitimized through liberal political philosophy, which both manufactures and obscures the racialized dichotomies which facilitate the imprisonment of those seeking entry to the Global North. The extant literature has lacked an acknowledgement of such dynamics.

Scholarship produced thus far has offered two predominant approaches to the topic. First was a more systematic, technical approach using policy diffusion scholarship. The frameworks produced by this field of study are useful yet run the risk (evidenced in the work considered) of decontextualizing or failing to historicize the objects of study. The second avenue viewed the issue through a political economic lens, centering not only the context of a distinctly unequal global history but also the inherently exploitative nature of a capitalist economy. The latter, I argue, provides a more comprehensive analysis of the globalization of noncitizen detention, yet still requires a more direct acknowledgement of the 
systems of racialization which serve to legitimize, and therefore stabilize such regimes.

As states continue to expand regimes of noncitizen detention, the industries which draw value from these systems will continue to grow in both scope and influence. The human costs of these practices will rise, as increasing numbers of migrants find themselves caught up in the global detention industry. As climate breakdown produces new or inflated migration streams and late-stage capitalism leaves workers increasingly vulnerable to crisis, understanding the institutions which these populations will encounter is of utmost importance. Absent from this inquiry are several questions. One concerns the distinctly gendered experiences of migration, an analysis of which would allow for a more nuanced understanding of these regimes. How families experience these systems is yet another question, as children represent perhaps the most vulnerable group of all.

Ultimately, the significance of this inquiry and others which may arise from it is that those who oppose such regimes - and the global capitalist order at large - must possess an understanding of the sites of tension where effective challenges may be mounted. The sites of imperial subjectification analyzed herein represent such opportunities. Whether these challenges would progress best in legal arenas seeking to leverage the power of states, or rather via social movements and insurgent tactics is similarly beyond the scope of this effort. Whatever avenues challengers choose, they will require critical analysis as a foundation.

\section{References}

Bales, K., \& Mayblin, L. (2018). Unfree Labour in Immigration Detention: Exploitation and Coercion of a Captive Immigrant Workforce. Economy and Society, 47(2), 191-213.

Dawson, M. (2016). Hidden in plain sight: A note on legitimation crises and the racial order. Critical Historical Studies 3(1), 143-161.

Flynn, M. (2014). There and back again: On the diffusion of immigration detention. Journal on Migration and Human Security 2(3), 165-197.

Flynn, M. \& Cannon, C. (2009). The privatization of immigration detention: Towards a global view. (Global Detention Project Working Paper No. 1). Geneva: Global Detention Project. 
Fraser, N. (2014). Behind Marx's Hidden Abode: For an Expanded Conception of Capitalism. New Left Review 86, 55-72.

Fraser, N. (2016). Expropriation and Exploitation in Racialized Capitalism: A Reply to Michael Dawson. Critical Historical Studies 3(2), 163-178.

Gilmore, R. W. (2007). Golden Gulag: Prisons, Surplus, Crisis, and Opposition in Globalizing California. Berkeley: University of California Press.

Gottschalk, M. (2014). Caught: The Prison State and the Lockdown of American Politics. (Course Book ed.). Princeton: Princeton University Press.

Lavenex, S. \& Uçarer, E. (2004). The External Dimension of Europeanization: The Case of Immigration Control. Cooperation and Conflict 39(4), 41743.

Lowe, L. (2015). The Intimacies of Four Continents. Durham and London: Duke University Press.

Martin, L. (2015). Noncitizen Detention: Spatial Strategies of Migrant Precarity in US Immigration and Border Control. Annales de Géographie, 702/703, 231-247.

Marx, K. \& Engels, F. (2011). Capital, Volume 1. New York: Dover (Original work published in 1867).

Morris, J. C. (2019). Violence and extraction of a human commodity: From phosphate to refugees in the Republic of Nauru. The Extractive Industries and Society 6(4), 1122-1133. 